\title{
The relationship between sandy beach nematodes and environmental characteristics in two Brazilian sandy beaches (Guanabara Bay, Rio de Janeiro)
}

\author{
TATIANA F. MARIA ${ }^{1,2}$, PAULO PAIVA ${ }^{3}$, ANN VANREUSEL $^{1}$ and ANDRÉ M. ESTEVES ${ }^{4}$ \\ ${ }^{1}$ Ghent University, Biology Department, Marine Biology, Krijgslaan 281- S8, B-9000 Ghent, Belgium \\ ${ }^{2}$ Departamento de Ecologia e Recursos Marinhos, Universidade Federal do Estado do Rio de Janeiro (UNIRIO), \\ Av. Pasteur, 458, Urca, 22290-240 Rio de Janeiro, RJ, Brasil \\ ${ }^{3}$ Universidade Federal do Rio de Janeiro, Departamento de Zoologia, Instituto de Biologia, \\ Av. Carlos Chagas Filho, 373, Ilha do Fundão, 21941-590 Rio de Janeiro, RJ, Brasil \\ ${ }^{4}$ Universidade Federal de Pernambuco, Departamento de Zoologia, \\ Av. Prof. Moraes Rêgo, s/n, Cidade Universitária, 50670-901 Recife, PE, Brasil
}

Manuscript received on January 18, 2012; accepted for publication on June 11, 2012

\begin{abstract}
We investigated if the differences in density and nematode communities of intertidal sediments from two Brazilian sheltered sandy beaches were related to environmental characteristics. The upper tide level (UTL) and the low tide level (LTL) of both beaches were surveyed in January (austral summer) and June 2001 (austral winter) during low-spring tides, by collecting samples of nematodes and sediments. Differences in density between beaches, tidal level and seasons, and nematode community structure were investigated. Sediments from both beaches were composed of medium to very coarse sand. The highest nematode densities were found at the UTL, and significant differences between beaches, tidal levels and months were found. A total of 54 genera were found and the genera composition on both sheltered beaches was similar to other exposed worldwide sandy beaches. The density and structure of the nematode community at both beaches clearly varied along the spatial and temporal scales. Gravel percentage was the most important variable explaining the spatial distribution of the nematodes, determining the four sub-communities; this suggests that the sediment characteristics influence the nematode community, rather than physical hydrodynamic forces. Temperature and salinity were suggested to be important variables affecting the temporal variation.
\end{abstract}

Key words: Brazil, free-living marine nematodes, hydrodynamic, granulometry, sandy beach.

\section{INTRODUCTION}

Sandy beaches are dynamic environments bordering many temperate and tropical coastlines, where they are extensively exploited commercially as recreational areas and used as buffer zones against the sea (McLachlan and Brown 2006). At first

Correspondence to: Tatiana F. Maria

E-mail: tatiana_fabricio@yahoo.com.br glance, these beaches may seem to be marine deserts; however, the sediment provides a threedimensional habitat that provides a substratum for diverse endobenthic communities (Gray 2002). These communities include species of different sizes of organisms, such as micro-, meio- and macrobenthos. Among the meiobenthos, sandybeach sediments are generally dominated by 
harpacticoid copepods and nematodes, with the dominance of one group over the other relating to grain size. The importance of the sediment for the distribution of animals on soft bottoms was first debated by Ford (1923) and an exhaustive discussion of this topic is found in Snelgrove and Butman (1994). The presence of nematodes as a group is independent of the sediment composition (Vanaverbeke et al. 2000), but, in general, nematodes are said to be highly dominant in sand finer than $300 \mu \mathrm{m}$, while harpacticoid copepods become more important in sediments coarser than $350 \mu \mathrm{m}$ (McLachlan and Brown 2006). Several studies have demonstrated the importance of median grain size, silt content and sorting as key aspects structuring the composition and diversity of free-living nematodes (Wieser 1959, Heip and Decraemer 1974, Ward 1973, Vincx et al. 1990, Vanaverbeke et al. 2002). Wieser (1959) showed that the nematode species distribution in sandybeach sediments is much better explained by granulometric changes than by tidal levels.

Several studies of sandy-beach nematodes show that the dominance of a nematode family is related to granulometric features (Sharma and Webster 1983, Gourbault and Warwick 1994, Nicholas and Hodda 1999, Gheskiere et al. 2004, Urban-Malinga et al. 2004, Calles et al. 2005, Hourston et al. 2005, Moreno et al. 2006, Mundo-Ocampo et al. 2007). Generally, sheltered areas with fine sand and mud are richer, while beaches exposed to oceanic waves are speciespoor (Gray 2002). The aim of this study was to investigate if the differences in density and nematode communities of intertidal sediments of two Brazilian sheltered sandy beaches located in a protected bay are related to differences in sediment composition.

\section{MATERIALS and METHODS}

STUDY AREA

Guanabara Bay $\left(22^{\circ} 24^{\prime}-22^{\circ} 57^{\prime} \mathrm{S}\right.$ and $\left.42^{\circ} 33^{\prime}-43^{\circ} 19^{\prime}\right)$ is a coastal inlet located in the second most densely populated state of Brazil, Rio de Janeiro, and has an area of $384 \mathrm{~km}^{2}$. The bay is connected to the sea by an access $1.6 \mathrm{~km}$ wide (Kjerfve et al. 1997). Two well defined seasons occur in this area, a rainy (December to April) and a dry (June to October) season, which consequently leads to a regional seasonal pattern with lower salinities in summer and higher salinities in winter (Paranhos and Mayr 1993). Annual mean water temperatures range from $25^{\circ} \mathrm{C}$ at the surface to $23.7^{\circ} \mathrm{C}$ in the bottom layer (Paranhos and Mayr 1993). Salinity decreases from the outer bay (34.6) toward the inner areas (26.1) (Kjerfve et al. 1997). In general, the bay has calm waters with low swells and gentle winds, predominantly from the east (Amador 1997). This bay has undergone great anthropogenic impact since Brazil's colonization; human activities since then have led to major alterations of landscapes and changes in biological, physical and chemical features (Amador 1997). Its basin is densely urbanized, and pollution by untreated domestic sewage is considered to be the worst environmental problem in the bay, making it one of the most heavily impacted and degraded ecosystems in Brazil (Mayr et al. 1989). Areas of severe sewage contamination were identified by higher concentrations of coprostanol (Carreira et al. 2002). Bacterial activity reaches up to $7.35 \mu \mathrm{g} \mathrm{C} \mathrm{L^{-1 }}$ $\mathrm{h}^{-1}$ in the inner part of the bay where tidal circulation is restricted (Andrade et al. 2003). However, Guanabara Bay is considered one of the most productive marine ecosystems in the world, with carbon assimilation values ranging between 800 and 3,600 mg.C.day ${ }^{-1}$ and a mean net primary production of 0.17 mol.C. $\mathrm{m}^{-2}$. day $^{-1}$ (Rebello et al. 1988).

In this bay, two microtidal, sheltered sandy beaches, Bananal and Coqueiros, were surveyed in January (austral summer) and June 2001 (austral winter) during low-spring tides. Bananal Beach is located on the largest island in the bay (Ilha do Governador) in the middle of the bay. According to Mayr et al. (1989), this beach is located in a sector of intermediate water quality with medium- to coarsesand sediments. Coqueiros Beach is located on a 


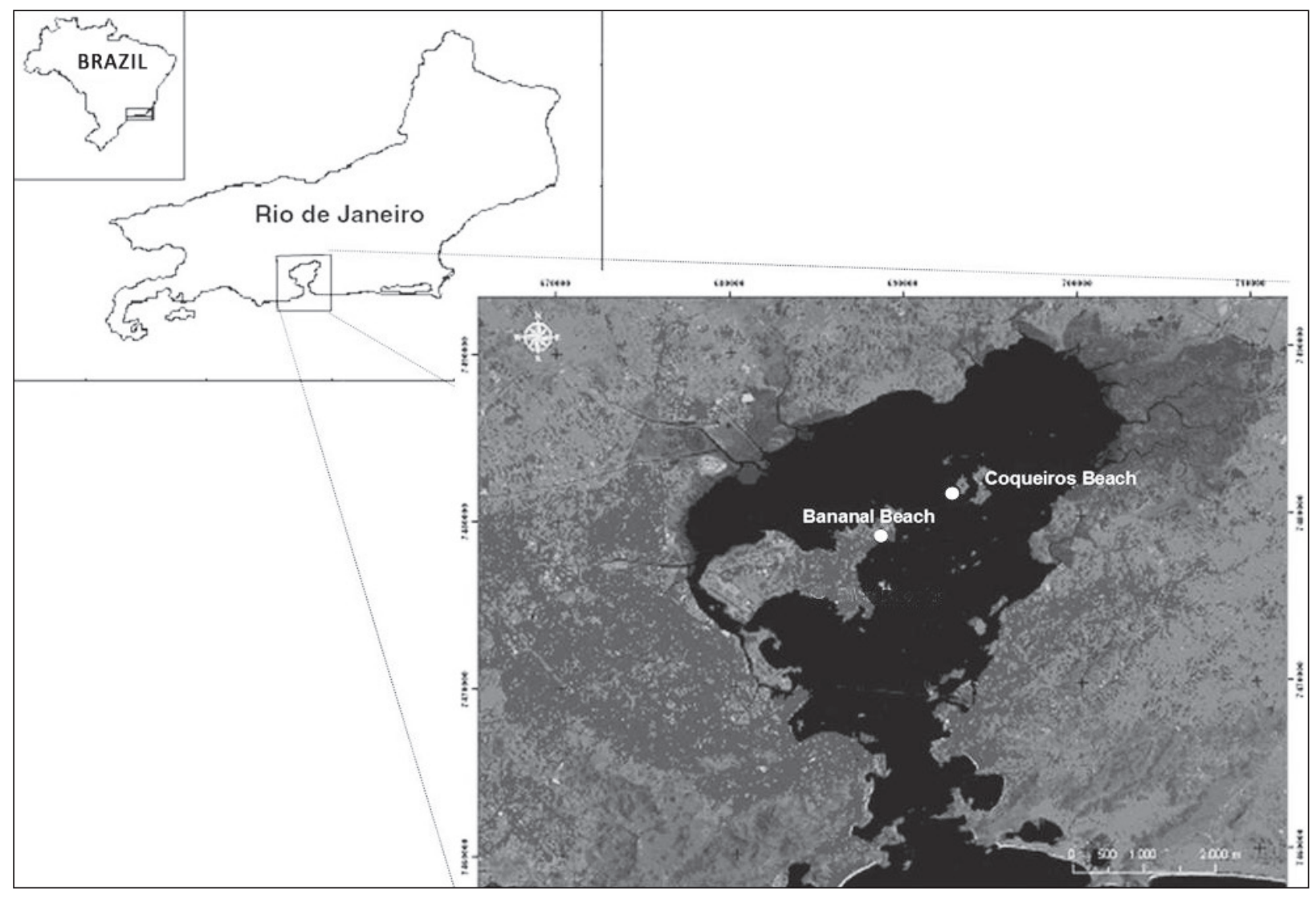

Fig. 1 - Guanabara Bay LANDSAT TM542 image, obtained by the Remote Sensing Laboratory of UFRJ. The locations of the beaches are indicated by white circles.

small island in the inner bay, where the best water quality is found because of the entrance of oceanic water during high tide (Mayr et al. 1989), and its sediment is composed of very coarse sand (Fig. 1).

\section{SAMPLING STRATEGY AND LABORATORY TREATMENT}

At both beaches, two stations were established: the low tide level (LTL) in the swash zone, and the upper tide level (UTL) $10 \mathrm{~m}$ above the LTL. At each station, triplicate meiofauna samples were taken using a 20-cm long PVC corer with an inner diameter of $3.6 \mathrm{~cm}$, corresponding to a surface area of $10 \mathrm{~cm}^{2}$, and immediately fixed with $4 \%$ formaldehyde. Another corer of the same diameter was used to collect sediment for sediment analysis. Sediment temperature was measured using a soil thermometer.
Nematodes were extracted from the sediment by sugar flotation (Esteves and Silva 1998) and sieved over $500-\mu \mathrm{m}$ and $62-\mu \mathrm{m}$ sieves. Nematodes retained on the $62-\mu \mathrm{m}$ sieve were counted, and 200 individuals from each sample were picked randomly using a stereomicroscope and transferred to a solution of 5 parts glycerin, 5 parts ethanol and 90 parts distilled water. Finally, these nematodes were mounted on glass slides and identified to genus level using the pictorial keys of Warwick et al. (1998) and the Nemys database (Deprez et al. 2005).

Grain size analysis was performed through sediment sieving using an automatic shaker. The sediment fractions were defined according to the Wentworth scale (Bale and Kenny 2005). 


\section{STATISTICAL ANALYSIS}

The differences in density between beaches, tidal level and seasons were tested by three-way analysis of variance (Beach, Tidal level, Season) using $\mathrm{R}$ (R Development Core Team 2011). Data were log transformed to assume a normal distribution and to fulfill the assumption of homogeneity of variances. Diversity was represented by K-dominance curves (Clarke and Warwick 2001). The nematode community structure was analyzed by non-metric MultiDimensional Scaling (MDS) using Bray-Curtis Similarity on non-transformed density data from each replicate sample. Differences between groups of data were investigated by a two-way crossed ANOSIM test. The genera that contributed most to the similarity within groups were identified by the SIMPER method. BIOENV was applied to investigate the granulometric parameter that best explained the spatial distribution of the nematode community composition. All these analysis were performed using the PRIMER v6.1 software package (Clarke and Gorley 2006).

The nematode composition was compared with 32 surveys of worldwide sandy-beach nematodes, in which beaches were grouped according to their degree of exposure. These surveys were based on peer-reviewed publications (Gray and Rieger 1971, Platt 1977, Sharma and Webster 1983, Gourbault and Warwick 1994, Gourbault et al. 1998, Nicholas and Hodda 1999, Gheskiere et al. 2002, 2004, 2005a, b, Urban-Malinga et al. 2004, 2006, 2008, Calles et al. 2005, Hourston et al. 2005, Moreno et al. 2006, Nicholas 2001, 2006, Nicholas and Trueman 2005, Calles 2006, de Jésus-Navarette 2007, MundoOcampo et al. 2007, Gingold et al. 2010).

\section{RESULTS}

GRANULOMETRY

Sediments from both beaches were mainly composed of medium to very coarse sand (Table I). At Coqueiros Beach the median grain size corresponded to very coarse sediment, poorly sorted at both tidal levels, with the highest contribution from gravel. At Bananal Beach the sand was mainly coarse, except at UTL in January when the median grain size corresponded to medium sand, and the sorting coefficient ranged from moderate at UTL to poorly sorted at LT. Considering the horizontal profile of both beaches, the highest median grain size, contribution of gravel, and contribution of silt and clay were found at LTL, except at Coqueiros Beach in January when the percentage of silt and clay was higher at UTL (Table I). The percentage of gravel increased in June, but there was no change in the median grain size or in the sorting coefficient.

TABLE I

Granulometric parameters of Coqueiros and Bananal beaches.

\begin{tabular}{llcccc}
\hline & & \multicolumn{2}{c}{ Coqueiros beach } & \multicolumn{2}{c}{ Bananal beach } \\
& & UTL & LTL & UTL & LTL \\
\hline \multirow{4}{*}{ January } & mean grain size $(\mathrm{mm})$ & 1.472 & 1.621 & 0.433 & 0.885 \\
& \% of gravel & 2.37 & 23.69 & 0.61 & 5.46 \\
& \% of silt and clay & 0.40 & 0.24 & 0.17 & 0.47 \\
& sorting coeficient & 1.20 & 1.24 & 0.71 & 1.19 \\
\hline \multirow{4}{*}{ June } & mean grain size $(\mathrm{mm})$ & 1.258 & 1.470 & 0.566 & 0.777 \\
& \% of gravel & 5.26 & 26.18 & 2.18 & 10.79 \\
& \% of silt and clay & 0.20 & 0.51 & 0.08 & 3.69 \\
& sorting coeficient & 1.26 & 1.37 & 0.92 & 1.96 \\
\hline
\end{tabular}

\section{TEMPERATURE}

Temperatures showed similar patterns at both beaches: the same temperature was found at the UTL and the LTL in January $\left(29^{\circ} \mathrm{C}\right)$ in both beaches, whereas in June the UTL show lower temperatures $\left(22^{\circ}\right.$ at Coqueiros Beach and $24^{\circ}$ at Bananal Beach) than the LTL $\left(25^{\circ} \mathrm{C}\right.$ at both beaches $)$.

\section{Nematode Assemblages}

The highest nematode densities were found at the UTL of both beaches, ranging from $880 \pm 217$ to $3,148 \pm 430$ ind. $10 \mathrm{~cm}^{-2}$ (Fig. 2). The three-way ANOVA showed statistical differences between beaches, tidal levels and months separately, but no interaction was observed (Table II). Coqueiros Beach, UTL and June showed the highest density. 


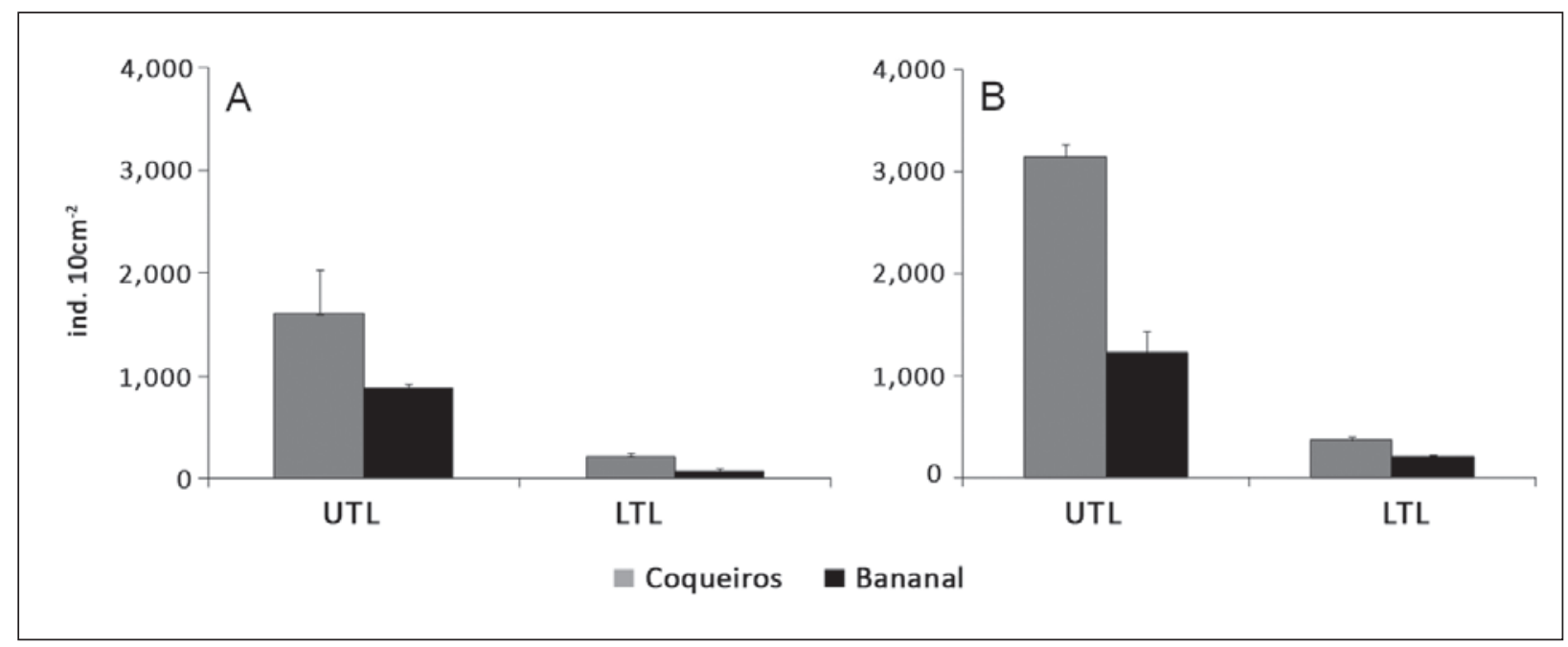

Fig. 2 - Mean density (ind. $10 \mathrm{~cm}^{-2} \pm$ standard error) of nematodes at the two tide levels on the two beaches investigated. A: January, B: June. UTL: upper tide level, LTL: low tide level.

TABLE II

Result of three-way ANOVA for density.

\begin{tabular}{lcrrr}
\hline & df & MS & F-value & p-value \\
\hline Beach & 1 & 0.83 & $556,900.0$ & $<\mathbf{0 . 0 1}$ \\
Level & 1 & $51,631.00$ & $3,459,571.0$ & $<\mathbf{0 . 0 1}$ \\
Month & 1 & 0.55 & $366,269.0$ & $<\mathbf{0 . 0 1}$ \\
beach $x$ level & 1 & 0.00 & 0.3 & 0.58 \\
beach $x$ month & 1 & 0.01 & 0.6 & 0.46 \\
level $x$ month & 1 & 0.03 & $22,744.0$ & 0.15 \\
beach $x$ level $x$ month & 1 & 0.06 & $39,633.0$ & 0.06 \\
Residuals & 16 & 0.01 & & \\
\hline
\end{tabular}

Significant differences are indicated in bold.

A total of 54 genera were found at the two beaches, belonging to 25 families. Chromadoridae and Cyatholaimidae contributed the highest number of genera at Coqueiros Beach; at Bananal Beach, Chromadoridae, Desmodoridae and Oncholaimidae were equally dominant families (Fig. 3).

Dracograllus was the dominant genus in the UTL of Coqueiros Beach, with $42 \%$ and $34 \%$ of relative abundance in January and June, respectively. Paracanthoncus (24\%) and Nygmatonchus (33\%) were the dominant genera in the UTL of Bananal Beach in January and June, respectively. In the LTL, Sabatieria was the abundant genus at Coqueiros Beach, corresponding to $50 \%$ and $63 \%$ of the relative abundance in January and June; and Theristus (75\%, January) and Chromaspirina (23\%, June) were most abundant at Bananal Beach (Appendix A). Comparison of the nematode composition with other beaches worldwide revealed that of the 54 genera found in this study, 46 have been reported from sandy beaches, including 35 for sheltered, 38 for intermediate and 39 for exposed sandy beaches.

The highest diversity was found in the UTL of both beaches in June, and the lowest diversity was found in the LTL of Bananal Beach. In June, the lowest diversity was found in the LTL of Coqueiros Beach (Fig. 4).

The multivariate analysis (MDS) clearly separated the nematode communities from the UTL to the LTL of both beaches. None of the communities of these tidal levels clustered together (Fig. 5A). There was a clear distinction between months within each beach and within each tidal level (Fig. 5B). The two-way crossed ANOSIM results confirmed that the nematode genera assemblages of these locations $(\mathrm{R}: 0.955, \mathrm{p}=0.001)$ and months (R: $0.593, p=0.001$ ) were significantly different.

The most abundant genus in each beach level was responsible for the similarity of the beach levels. In the case of the UTL, Nygmatonchus and 


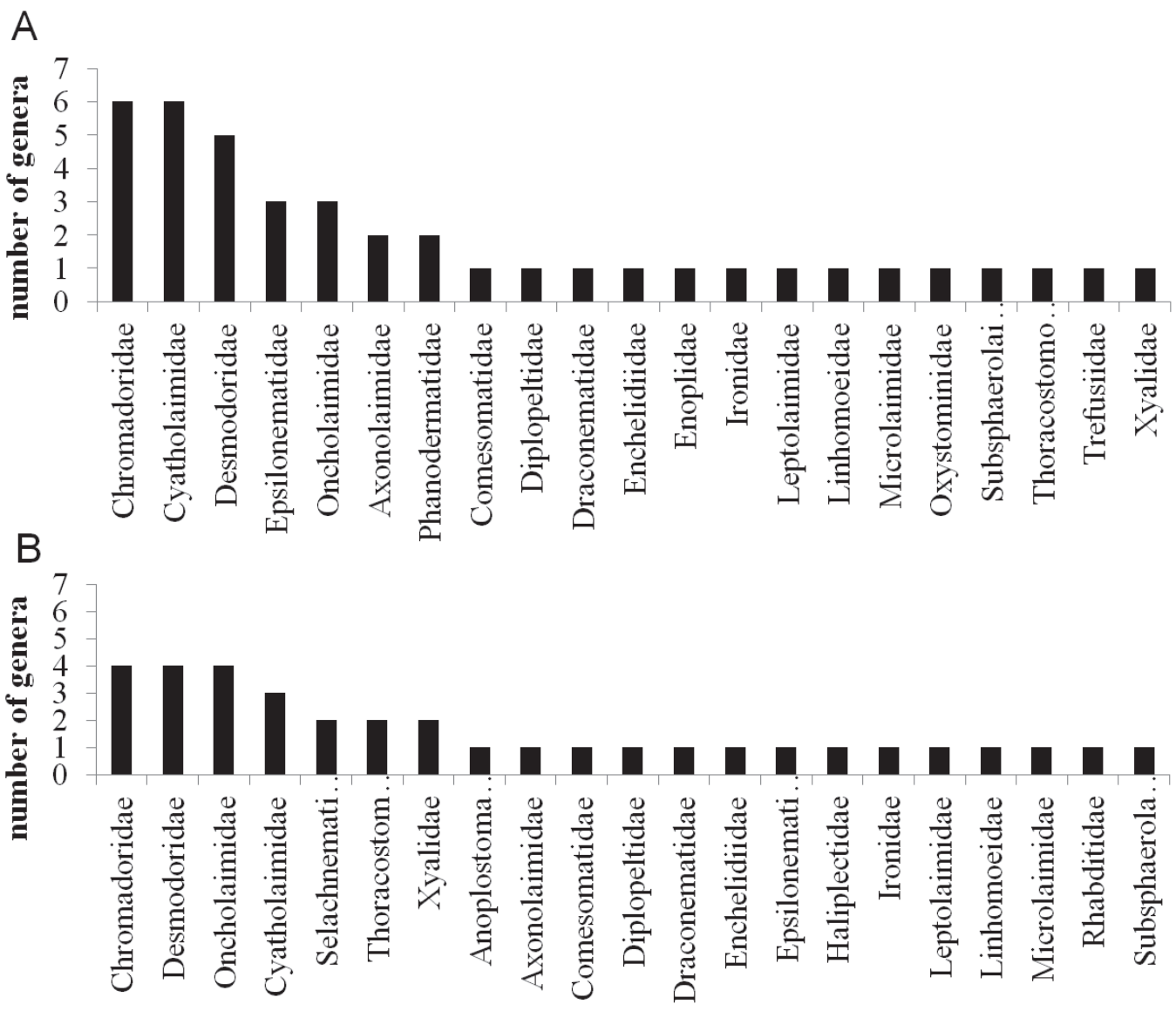

Families

Fig. 3 - Number of genera per family found per beach. A: Coqueiros beach, B: Bananal beach.

A

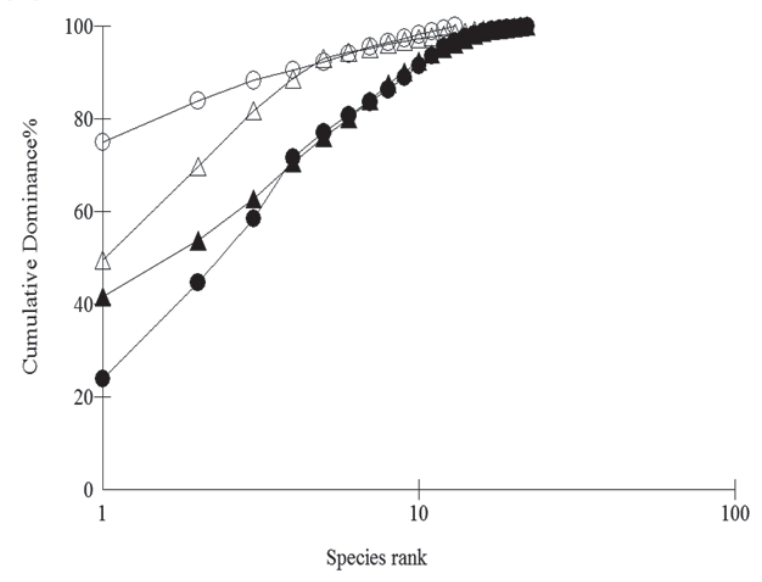

B

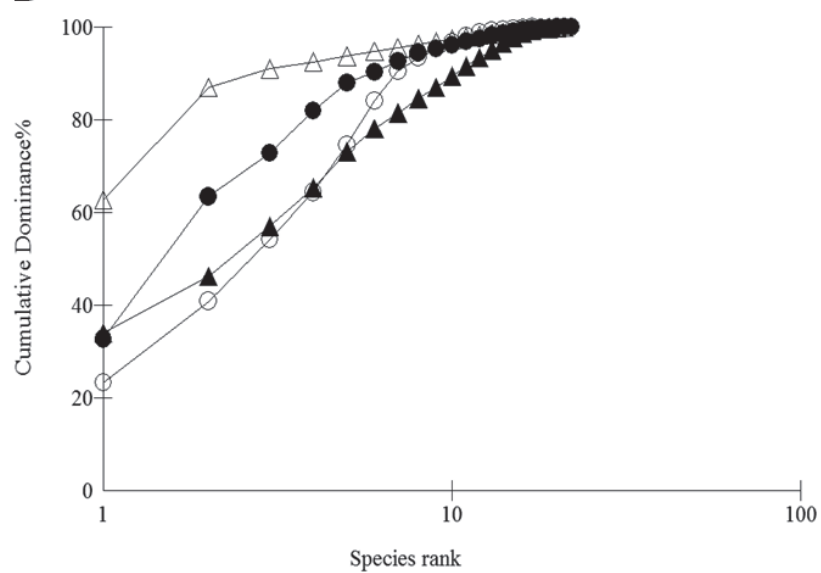

$\Delta$ CUTL $\triangle$ CLTL

- BaUTL

BaLTL

Fig. 4 - K-dominance curves for nematode genera data pooled over each tidal level. A: January, B: June. (CUTL: Coqueiros upper tide level, CLTL: Coqueiros low tide level, BaUTL: Bananal upper tide level, BaLTL: Bananal low tide level). 


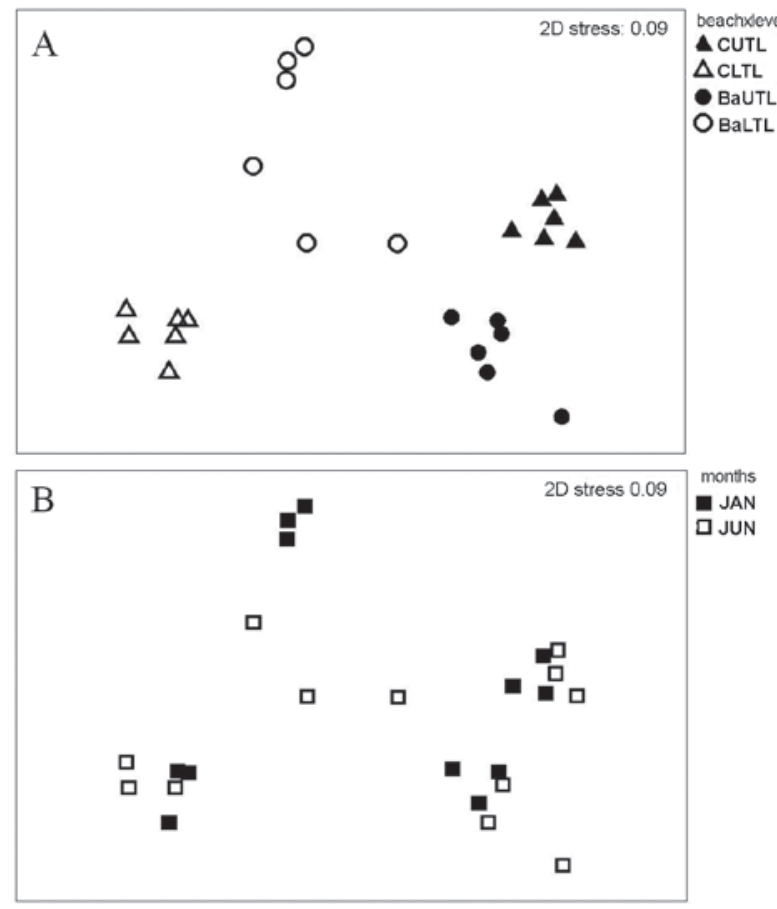

Fig. 5 - Nematode assemblages: output of non-metric MultiDimensional Scaling (MDS) based on non-transformed genus density. A: MDS of tidal levels and beaches; B: MDS for months. Abbreviations as showed in the previous figure.

Dracograllus contributed most to the similarity within Bananal and Coqueiros beaches, respectively. In the LTL, Theristus and Sabatieria showed the highest similarity percentages within Bananal and Coqueiros beaches, respectively (Table III).

The BIOENV results showed that the contribution of gravel correlated best with the community structure $(\rho=0.702, p=0.001)$.

\section{DISCUSSION}

\section{SPATIAL DISTRIBUTION}

The crossing of the cumulative curves of Bananal LTL and Coqueiros UTL did not enable us to distinguish the most diverse community in June, whereas in January higher diversity was observed in the UTL of Bananal, whereas higher density was found in the UTL of Coqueiros Beach in June. Considering that nematodes are highly abundant in sediments with a median grain size of $300 \mu \mathrm{m}$ (McLachlan and Brown
TABLE III

SIMPER-list showing the contribution (\%) of the most relevant genera to each beach and level, cut-off at $90 \%$.

\begin{tabular}{|c|c|c|c|c|}
\hline & \multicolumn{2}{|c|}{ UTL } & \multicolumn{2}{|c|}{ LTL } \\
\hline & $\begin{array}{c}\text { Bananal } \\
(48 \%)\end{array}$ & $\begin{array}{c}\text { Coqueiros } \\
(63 \%)\end{array}$ & $\begin{array}{c}\text { Bananal } \\
(44 \%)\end{array}$ & $\begin{array}{c}\text { Coqueiros } \\
(77 \%)\end{array}$ \\
\hline Chromadorita & 3 & 7 & & \\
\hline Chromaspirina & & & 18 & \\
\hline Desmodora & & & & 19 \\
\hline Desmodorella & & & & 9 \\
\hline Dracograllus & & 50 & & \\
\hline Epsilonema & & 3 & & \\
\hline Eurystomina & & & & 5 \\
\hline Metachromadora & 17 & 4 & 11 & \\
\hline Nygmatonchus & 36 & & & \\
\hline Oncholaimus & & 10 & & \\
\hline Paracanthoncus & 16 & & & \\
\hline Paracyatholaimus & & 10 & & \\
\hline Sabatieria & & & & 60 \\
\hline Subsphaerolaimus & 4 & & & \\
\hline Theristus & & & 67 & \\
\hline Trileptium & 3 & & & \\
\hline Trissonchulus & 13 & 7 & & \\
\hline
\end{tabular}

Overall similarity for each beach level is given in brackets.

2006), a high density would be expected to occur in the UTL of Bananal because the mean grain size is around this value. However, we observed the inverse; nematodes were much more abundant in very coarse sediments of $1.5 \mathrm{~mm}$ (UTL of Coqueiros). Although grain size directly affects the spatial and structural conditions of the interstitial matrix and indirectly determines the physical and chemical environment of the sediment, the most important characteristic of sands of different grain size is represented by their systems of interstitial spaces rather than solely the grain size (Wieser 1959). Sediment sorting is a principal factor determining meiofauna distribution (Hulings and Gray 1976, Urban-Malinga et al. 2004). In the UTL of Coqueiros Beach, the sediment was poorly sorted, meaning that there was a mixture of grades of sand that provides many more interstitial spaces for nematodes to inhabit. Coleman et al. (1997) also found that the number of individuals increased as the sediments became more poorly sorted. 
TEMPORAL DISTRIBUTION

In tropical and subtropical areas, nematodes show seasonal shifts that are mainly related to food availability (Alongi 1990a). High densities of nematodes from northern and southern temperate sandy beaches occur during spring, summer and autumn because abundant food sources are provided due to the increase in primary production during spring and summer that persists into autumn (Boaden and Platt 1971, Sharma and Webster 1983, Nicholas 2001, Hourston et al. 2005). However, in tropical areas, food is not a limiting factor. The beaches studied are located in a bay with constant input of domestic sewage (Mayr et al. 1989). Therefore, the high density of nematodes during June, austral winter, may be related to the temperature, as previously demonstrated by Alongi (1990b). Esteves et al. (2004) and Maria et al. (2008) also observed that some nematode species have high peaks of abundance during the winter in a tidal flat, located in another bay near Guanabara Bay. Another factor that may explain the seasonal variation is the difference in salinity; January and June are in the rainy and dry seasons, respectively. As a consequence, lower salinities occur in summer and higher salinities in winter (Paranhos and Mayr 1993). Nematodes are able to withstand differences in salinities, but species from the upper shore are more capable of osmoregulating than those found in the lower shore (Foster 1998). This scenario agrees with our findings of high density in the upper tidal level during the dry season.

\section{HYDRODYNAMIC X SEDIMENT CHARACTERISTICS}

In general, sheltered beaches have a predominance of fine sediment particles, and exposed beaches have coarse sediments (McLachlan and Brown 2006). This expected pattern was not observed in either beach, although this departure from the normal pattern is easily explained by the origin of the grains, through pluvial sedimentation during the Pleistocene. These pluvial sediments have remained until now because of the low hydrodynamic characteristics of these beaches in the interior of Guanabara Bay, and the unavailability of fine sediments to settle (Amador 1997).

In both beaches, the type of sediment was clearly reflected in the dominant fauna. Chromadoridae, Cyatholaimidae and Desmodoridae were the dominant families in terms of genera. The higher number of similar genera in Coqueiros Beach, Bananal beach, and exposed worldwide sandy beaches indicates a similarity among the studied beaches and the latter morphodynamic beach types. Three of the most abundant genera are dominant or belong to dominant families in the sediment of exposed sandy beaches: Dracograllus, Nygmathonchus and Theristus. The two latter genera belong to the families Chromadoridae and Xyalidae, respectively. Chromadoridae is a dominant family in sediments of exposed sandy beaches (Urban-Malinga et al. 2004). Although Xyalidae is a dominant family in fine to medium sand (Gourbault and Warwick 1994, Nicholas and Hodda 1999, Gheskiere et al. 2004, Hourston et al. 2005, Moreno et al. 2006, MundoOcampo et al. 2007), Theristus was also found to be a dominant genus in exposed and very coarse beaches (Gourbault et al. 1998, Urban-Malinga et al. 2004). Draconematids such as Dracognomus, Dracograllus, Draconema and Paradraconema occur in sediments ranging from medium to very coarse sand (Gheskiere et al. 2005a, A.M. Esteves (unpublished data) or coralline fragments (Gourbault et al. 1998, Netto et al. 1999, Raes and Vanreusel 2006), and their presence in these environments is attributed to their adaptation to substrate instability that is often associated with coarse substrates (Raes and Vanreusel 2006). Draconematids can attach themselves to large grains by using their ambulatory setae and caudal glands, avoiding being washed away by waves and current movements (Raes et al. 2006); in addition, a large 
particle size is required for their atypical crawling locomotion, consisting of alternate movements with intervals of attachment and release of the anterior and posterior body regions (Stauffer 1924).

On the other hand, Sabatieria, the dominant genus in the LTL of Coqueiros Beach, occurs relatively infrequently in exposed sandy beaches (only 4 of 19 exposed beaches previously studied) and has no apparent relationship with this environment. For some Sabatieria species such as $S$. punctata and $S$. celtica, the contribution of fine sediments seems to be much more important (Vanreusel 1991), but surprisingly this genus was not found in the LTL of Bananal Beach where a high percentage of fine sediments was found. Smol et al. (1994) also reported this genus from sites with less than 5\% silt. Perhaps its presence is related to the degree of pollution of the bay. Sabatieria is a genus that indicates poor ecological quality of the environment, because of its well-known tolerance to pollution (Moreno et al. 2011).

In general, the degree of exposure of a sandy beach is reflected in the sediment properties; very exposed sandy beaches often have intense hydrodynamism and medium to coarse sediments (McLachlan and Brown 2006). Therefore, the species occurring in highly hydrodynamic environments must have some adaptations to inhabit these beaches and to cope with rapidly changing conditions (Schlacher et al. 2008). As both beaches are sheltered, it is surprising to find a community adapted to high hydrodynamic forces. Sediment characteristics seem to better explain the community structure, since the gravel percentage is the sediment variable that better correlated with the nematode communities in both beaches. Therefore, the occurrence of nematode genera in an environment seems to be more related to the sediment characteristics, rather than to their ability to cope with intense physical disturbance. Morphological adaptations and species characteristics are important in favoring the survival of a genus or species in a dynamic environment, but according to our results the sediment characteristics, rather than any hydrodynamic forces, drive the nematode community structure in sandy-beach sediments of the Guanabara Bay.

In conclusion, the density and structure of the nematode community at both beaches in Guanabara Bay clearly varied along the spatial and temporal scales. Gravel percentage was the most important variable controlling the spatial distribution of the nematodes, determining the four sub-communities (LTL and UTL of Bananal and Coqueiros beaches, separately); whereas temperature and salinity are suggested to be important for the temporal variation, differentiating the summer and winter communities of each tidal level within each beach.

\section{ACKNOWLEDGMENTS}

Gratitude is expressed to PETROBRAS that supported the project 'Biomonitoring of sandy beaches of Guanabara Bay after the oil spill in January 2000'; to Prof. Vera Abud (Dept. Zoology/ UFRJ) for allowing us to work with the material derived from that project, and to Nic Smol for help in identifying the nematodes. Dr. Janet W. Reid, JWR Associates is acknowledged for her critical revision of the English. The first author was sponsored by Coordenação de Aperfeiçoamento de Pessoal de Nível Superior (CAPES) and the Program Alßan - the European Union Program of High Level Scholarships for Latin America, scholarship no. E05M049715BR.

\section{RESUMO}

Foi investigado se a diferença entre a densidade e a comunidade de nematódeos dos sedimentos entre-marés de duas praias arenosas protegidas no Brasil estava relacionada com características ambientais. Durante as marés de sizígia de janeiro (verão austral) e junho (inverno austral) de 2001, amostras de sedimentos e nematódeos foram coletadas no médio litoral superior (UTL) e o médio litoral inferior (LTL). Diferenças na densidade e na estrutura da comunidade de nematódeos entre praias, 
níveis de maré e estações do ano foram investigadas. $\mathrm{O}$ sedimento de ambas as praias foi composto por areia média ou areia muito grossa. A maior densidade de nematódeos foi encontrada no UTL e significativamente diferente entre praias, níveis de maré e meses do ano. Um total de 54 gêneros foi encontrado e a composição genérica de ambas as praias protegidas foi similar a de outras praias expostas ao redor do mundo. A densidade e a estrutura da comunidade de ambas as praias variou ao longo das escalas espacial e temporal. A porcentagem de cascalho foi a variável ambiental que melhor explicou a distribuição espacial dos nematódeos, determinando as quatro sub-comunidades; isso sugere que as características do sedimento controlam a comunidade de nematódeos em detrimento a forças físicas hidrodinâmicas. A temperatura e a salinidade foram sugeridas como variáveis ambientais importantes afetando a variação temporal.

Palavras-chave: Brasil, nematódeos marinhos de vida livre, hidrodinamismo, granulometia, praia arenosa.

\section{REFERENCES}

ALONGI DM. 1990a. The ecology of tropical soft-bottom benthic ecosystems. Oceanogr Mar Biol 28: 381-496.

ALONGI DM. 1990b. Community dynamics of free-living nematodes in some tropical mangrove and sandflats. B Mar Sci 46: 358-373.

AMADOR ES. 1997. Baía de Guanabara e ecossistemas periféricos: homem e natureza. Ed. Reproarte, Rio de Janeiro, $539 \mathrm{p}$.

ANDrade L, GonZalez AM, ARAÚJo FV and Paranhos R. 2003. Flow cytometry assessment of bacterioplankton in tropical marine environments. J Microbiol Meth 55: 841-850.

BALE AJ AND KenNY AJ. 2005. Sediment analysis and seabed characterization. In: ELEFTHERIOU A AND MCINTYRE A (Eds), Methods for the Study of Marine Benthos, Blackwell, Oxford, p. 43-86.

BOADEN PJS AND PLATT HM. 1971. Daily migration patterns in an intertidal meiobenthic community. Thalassia Jugos 7: 1-12.

Calles A, Vincx M, Cornejo P ANd Calderón J. 2005. Patterns of meiofauna (especially nematodes) in physical disturbed Ecuadorian sandy beaches. Meiofauna Marina 14: 121-129.

CALLES AK. 2006. Spatial and temporal patterns of meiofauna along Ecuadorian sandy beaches, with a focus on nematode biodiversity. PhD Thesis. Universiteit Gent, Gent, Belgium.
CARreira RS, WAgner ALR, REAdMAn J, Fileman MSA AND VEIGA A. 2002. Changes in the sedimentary organic carbon pool of a fertilized tropical estuary, Guanabara Bay, Brazil: an elemental, isotopic and molecular marker approach. Mar Chem 79: 207-227.

Clarke K AND Gorley RN. 2006. Primer v6: User Manual/ Tutorial. PRIMER-E: Plymouth.

ClARKE K AND WARWICK RM. 2001. A further biodiversity index applicable to species lists: variation in taxonomic distinctness. Mar Ecol Prog Ser 216: 265-278.

Coleman N, Gason AS And Poore GCB. 1997. High species richness in the shallow marine waters of southeast Australia. Mar Ecol Prog Ser 154: 17-26.

DE JESÚS-NAVARRETE A. 2007. Littoral free-living nematode fauna of Socorro Island, Colima, Mexico. Hidrobiologica 17: 61-66.

DePreZ T ET AL. 2005. NeMys. World Wide Web electronic publication. www.nemys.ugent.be

ESTEVES AM AND DA SILVA VMAP. 1998. The behaviour of sugar flotation technique in meiofauna extraction from different sand types. Trop Ecol 39: 283-284.

EsteVes AM, MARIA TF AND WANDENESS AM. 2004. Population structure of Comesoma arenae Gerlach (Nematoda: Comesomatidae) in a Brazilian tropical tidal flat, Rio de Janeiro, Brazil. Rev Bras Zool 21: 775-777.

ForD E. 1923. Animal communities of the level sea-bottom in the waters adjacent to Plymouth. J Mar Biol Ass UK 13: $164-224$.

FOSTER SJ. 1998. Osmotic stress tolerance and osmoregulation of intertidal and subtidal nematodes. J Exp Mar Biol Ecol 224: 109-125.

Gheskiere T, Hoste E, Kotwicki L, Degraer S, VANAVERBEKE J AND VINCX M. 2002. The sandy beach meiofauna and free-living nematodes from De Panne (Belgium). Biologie 72: 43-49.

GHeskiere T, Hoste E, VAnaVerbeke J, VincX M AND DEGRAER S. 2004. Horizontal zonation patterns and feeding structure of marine nematode assemblages on a macrotidal, ultra-dissipative sandy beach De Panne, Belgium. J Sea Res 55: 221-226.

GHESKIERE T, VinCX M, URBAN-MALINGA B, RossAno C, SCAPINI F AND DEGRAER S. 2005a. Nematode from wavedominated sandy beaches: diversity, zonation, patterns and testing iso-communities concept. Estuar Coast Shelf Sci 62: 365-375.

GHESKIERE T, VinCX M, WESLAWSKI JM, SCAPINI F AND DEGRAER S 2005b. Meiofauna as descriptor of tourisminduced changes at sandy-beaches. Mar Environ Res 60: 245-265.

GingOLD R, MUNDO-OCAMPO M, HOLOVACHOV O AND ROCHA-OLIVARIS A. 2010. The role of habitat heterogeneity in structuring the community of intertidal free-living marine nematodes. Mar Biol 157: 1741-1753.

GOURBAULT N AND WARWICK RM. 1994. Is the determination of meiobenthic diversity affected by the sampling method in sandy beaches? Mar Ecol 15: 267-279. 
Gourbault N, WARWick RM AND HelléOUet MN. 1998. Spatial and temporal variablity in the composition and structure of meiobenthic assemblages (especially nematodes) in tropical beaches ( Guadeloupe, FWI). Cah Biol Mar 39: 29-39.

GRAY JS. 2002. Species richness of marine soft sediments. Mar Ecol Prog Ser 244: 285-297.

GRAY JS AND RIEGER RM. 1971. A quantitative study of the meiofauna of an exposed sandy beach, at Robin Hood's Bay, Yorkshire. J Mar Biol Ass UK 51: 1-19.

HeIP C AND DeCRAEMER W. 1974. The diversity of nematode communities in the southern North Sea. J Mar Biol Ass UK 54: 251-255.

Hourston M, WARWICK RM, VALESINI FJ AND POTTER IC. 2005. To what extent are the characteristics of nematode assemblages in nearshore sediments on the west Australian coast related to habitat type, season and zone? Estuar Coast Shelf Sci 64: 601-612.

Hulings NC AND GRAY JS. 1976. Physical factors controlling abundance of meiofauna on tidal and atidal beaches. Mar Biol 74: 77-83.

KJERFVE B, RiBEIRO CHA, DiAS GTM, FilipPo AM AND QUARESMA VS. 1997. Oceanographic characteristics of an impacted coastal bay: Baía de Guanabara, Rio de Janeiro, Brazil. Cont Shelf Res 17: 1609-1643.

MARIA TF, DA SILVA NRR, WANDENESS AP AND ESTEVES AM. 2008. Spatio-temporal study and population structure of Daptonema oxycerca (Nematoda: Xyalidae) in Coroa Grande, Rio de Janeiro, Brazil. Braz J Oceanogr 56: 41-50.

Mayr LM, Tenenbaum DR AND Villac MC. 1989. Hydrobiological characterization of Guanabara Bay. VIth Symposium on Coastal Management (Coastal Zone 89), p. 124-138.

MCLACHLAN A AND BROWn A. 2006. The ecology of sandy shores. Elsevier, USA, 373 p.

Moreno M, Ferrero TJ, Granelli V, Marin V, Albertelli G AND FABIANO M. 2006. Across shore variability and trophodynamic features of meiofauna in a microtidal beach of the NW Mediterranean. Estuar Coast Shelf Sci 66: 357-367.

Moreno M, SEMPrUCCI F, VeZzULli L, BALSAMo M, FABiAnO M And Alebertelli G. 2011. The use of nematodes in assessing ecological quality status in the Mediterranean coastal ecosystems. Ecol Ind 11: 328-336

Mundo-OCAMPO M ET AL. 2007. Biodiversity of littoral nematodes from two sites in the Gulf of California. Hydrobiologia 586: 179-189.

NetTo SA, WARWICK RA AND ATTRIL MJ. 1999. Meiobenthic and macrobenthic community structure in carbonate sediments of Rocas Atoll (North-east, Brazil). Estuar Coast Shelf Sci 48: 39-50.

NiCHOLAS WL. 2001. Seasonal variations in nematode assemblages on an Australian temperate ocean beach; the effect of heavy seas and unusually high tides. Hydrobiologia 464: 17-26.
NiCHOLAS WL. 2006. The meiofauna of a new South Wales sandy beach: an introduction to the meiofauna of Australian ocean beaches. Wetlands 23: 14-31.

NichOlas WL AND HodDA M. 1999. The free-living nematodes of a temperate, high energy, sandy beach, faunal composition and variation over space and time. Hydrobiologia 394: 113-127.

Nicholas WL AND TRUeman JWH. 2005. Biodiversity of marine nematodes in Australian sandy beaches from tropical and temperate regions. Biodivers Conserv 14: 823-839.

PARANHOS R AND MAYR LM. 1993. Seasonal patterns of temperature and salinity in Guanabara Bay, Brazil. Fresenius Environ Bull 2: 647-652.

PLATT HM. 1977. Vertical and horizontal distribution of freeliving marine nematodes from Strangford Lough, Nothern Ireland. Cah Biol Mar 5: 685-693.

R Development Core Team 2011. R: A language and environment for statistical computing. R Foundation for Statistical Computing,Vienna, Austria. URL http:// www.r-project.org.

Raes M, De Troch M, Ndaro SGH, Muthumbi A, Guilini K AND VANREUSEL A. 2006. The structuring role of microhabitat type in coral degradation zones: a study with marine nematodes from Kenya and Zanzibar. Coral Reef 26: 113-126.

Raes M AND VAnReusel A. 2006. Microhabitat types determine the composition of nematodes communities associated with sediment-clogged cold-water coral framework in the Porcupine Seabight (NE Atlantic). Deep-Sea Res 53: 1880-1894.

Rebello AL, PonCiAno CR AND Melges LH. 1988. Avaliação da produtividade primária e da disponibilidade de nutrientes na Baía de Guanabara. An Acad Bras Cienc 60: 419-430.

SCHLACHER TA, Schoeman DS, Dugan J, LASTRA M, Jones A, SCAPINI F AND MCLACHLAN A. 2008. Sandy beach ecosystems: key features, sampling issues, management challenges and climate change impacts. Mar Ecol 29: 70-90.

SHARMA J AND WEBSTER JM. 1983. The abundance and distribution of free-living nematodes from two Canadian Pacific beaches. Estuar Coast Shelf Sci 16: 217-227.

Smol N, Willens KA, Govaere JCR And SAndeE AJJ. 1994. Composition, distribution and biomass of meiobenthos in the Oosterschelde estuary (SW Netherlands). Hydrobiologia 282-283: 197-217.

SNELGROVE PVR AND BUTMAN CA. 1994. Animal-sediment relationships revisited: cause versus effect. Oceanogr Mar Biol 32: 111-177.

STAUFFER H. 1924. Die Lokomotion der Nematoden. Beiträge zur Kausalmorphologie der Fadenwürmer. Zoologischer Jahrbücher 49: 1-118.

Urban-Malinga B, Gheskiere T, Degraer S, Derycke S, OpalinsKi KW AND Moens T. 2008. Gradients in biodiversity and macroalgal wrack decomposition rate across a macrotidal, ultradissipative sandy beach. Mar Biol 155: 79-90. 
Urban-Malinga B, HedtKamp SiC, VAn Beusekom JEE, WiKTOR J AND Weslawski JM. 2006. Comparison of nematode communities in Baltic and North Sea sublittoral, permeable sands - Diversity and environmental control. Estuar Coast Shelf Sci 70: 224-238.

Urban-MALINGA LK, GHESKIERE TLA, JANKOWSKA K, OPALIÑSKI K AND MALINGA M. 2004. Composition and distribution of meiofauna, including nematode genera, in two contrasting Arctic beaches. Polar Biol 27: 447-457.

VANAVERBeKe J, GHeskiere T, Steyaert M AND VinCX M. 2002. Nematode assemblages from subtidal sandbanks in the Southern Bight of the North Sea: effect of small sedimentological differences. J Sea Res 48: 197-207.

VANAVERBEKE J, GHESKIERE T AND VINCX M. 2000. The meiobenthos of subtidal sandbanks on the Belgian Continental Shelf (Southern Bight of the North Sea). Estuar Coast Shelf Sci 51: 637-649.
VANREUSEL A. 1991. Ecology of free-living marine nematodes in the Voordelta (Southern Bight of the North Sea). II. Habitat preferences of the dominant species. Nematologica 37: 343-359.

VINCX M, MEIRE P AND HEIP C. 1990. The distribution of the nematodes communities in the southern Bight of the North Sea. Cah Biol Mar 31: 107-129.

WARD AR. 1973. Studies on the sublittoral free-living nematodes of Liverpool Bay. I. The structure and distribution of the nematode populations. Mar Biol 22: 53-66.

WARWICK RM, PlatT HM AND SOMERFIELD PJ. 1998. Freeliving marine nematodes. Part 3. British Monhysterids. The Linnean Society of London and the Estuarine and Coastal Sciences Association, London, 269 p.

WIESER W. 1959. The effect of grain size on the distribution of small invertebrates inhabiting the beaches of Puget Sound. Limnol Oceanogr 4: 181-194. 
APPENDIX A

Relative abundance of nematodes genera at the two studied beaches, considering the tide levels (UTL and LTL) and months (Jan=January and Jun=June). FT $=$ feeding types.

\begin{tabular}{|c|c|c|c|c|c|c|c|c|c|}
\hline \multirow{3}{*}{ Genera } & \multirow{3}{*}{ FT } & \multicolumn{4}{|c|}{ Coqueiros } & \multicolumn{4}{|c|}{ Bananal } \\
\hline & & \multicolumn{2}{|c|}{ Upper } & \multicolumn{2}{|c|}{ Lower } & \multicolumn{2}{|c|}{ Upper } & \multicolumn{2}{|c|}{ Lower } \\
\hline & & Jan & Jun & Jan & Jun & Jan & Jun & Jan & Jun \\
\hline Acanthoncus & $2 \mathrm{~A}$ & 0.00 & 0.00 & 0.17 & 1.07 & 0.00 & 0.00 & 0.00 & 0.41 \\
\hline Actinonema & $2 \mathrm{~A}$ & 0.00 & 0.00 & 0.00 & 0.00 & 0.00 & 0.09 & 0.00 & 0.20 \\
\hline Anoplostoma & $1 \mathrm{~B}$ & 0.00 & 0.00 & 0.00 & 0.00 & 2.56 & 2.34 & 0.00 & 0.00 \\
\hline Araeolaimus & $1 \mathrm{~A}$ & 0.00 & 0.00 & 0.00 & 0.00 & 0.00 & 0.03 & 0.00 & 0.00 \\
\hline Axonolaimus & $1 \mathrm{~B}$ & 0.00 & 0.00 & 0.18 & 0.00 & 0.00 & 0.00 & 0.58 & 0.00 \\
\hline Choanolaimus & $2 \mathrm{~A}$ & 0.00 & 0.00 & 0.00 & 0.00 & 3.65 & 0.94 & 0.00 & 0.00 \\
\hline Chromadora & $2 \mathrm{~A}$ & 0.00 & 0.00 & 0.17 & 0.00 & 0.00 & 0.00 & 0.00 & 0.00 \\
\hline Chromadorita & $2 \mathrm{~A}$ & 7.85 & 7.73 & 0.69 & 0.56 & 5.46 & 0.61 & 1.59 & 1.83 \\
\hline Chromaspirina & $2 \mathrm{~B}$ & 0.00 & 0.00 & 0.00 & 0.19 & 0.41 & 0.00 & 8.88 & 23.39 \\
\hline Desmodora & $2 \mathrm{~A}$ & 0.00 & 0.00 & 12.06 & 24.25 & 0.00 & 0.07 & 0.00 & 10.12 \\
\hline Desmodorella & $2 \mathrm{~A}$ & 0.00 & 0.00 & 20.11 & 1.48 & 0.00 & 0.00 & 0.00 & 0.00 \\
\hline Dracograllus & $1 \mathrm{~A}$ & 41.65 & 34.01 & 0.00 & 0.29 & 0.00 & 0.51 & 0.00 & 0.00 \\
\hline Enoploides & $2 \mathrm{~B}$ & 0.00 & 0.00 & 0.00 & 0.00 & 1.03 & 0.39 & 0.00 & 0.00 \\
\hline Enoplus & $2 \mathrm{~B}$ & 0.00 & 0.00 & 0.17 & 0.00 & 0.00 & 0.00 & 0.00 & 0.00 \\
\hline Epsilonema & $1 \mathrm{~A}$ & 4.09 & 3.35 & 0.00 & 0.14 & 0.00 & 30.67 & 0.00 & 0.00 \\
\hline Eurystomina & $2 \mathrm{~B}$ & 0.21 & 0.00 & 6.91 & 1.21 & 0.66 & 0.26 & 0.00 & 0.81 \\
\hline Haliplectus & $1 \mathrm{~A}$ & 0.00 & 0.00 & 0.00 & 0.00 & 0.18 & 0.00 & 0.00 & 0.00 \\
\hline Kosswigonema & $2 \mathrm{~B}$ & 0.00 & 0.00 & 0.00 & 0.00 & 0.00 & 0.00 & 0.86 & 0.00 \\
\hline Linhomoeus & $1 \mathrm{~B}$ & 0.00 & 0.00 & 0.00 & 0.00 & 0.00 & 0.07 & 0.00 & 0.00 \\
\hline Longicyatholaimus & $2 \mathrm{~A}$ & 0.00 & 0.00 & 0.00 & 0.80 & 0.00 & 0.00 & 0.00 & 0.00 \\
\hline Cyatholaimidae type I & $2 \mathrm{~A}$ & 2.62 & 0.34 & 0.00 & 0.00 & 0.00 & 0.00 & 0.00 & 0.00 \\
\hline Marylynnia & $2 \mathrm{~A}$ & 0.00 & 0.00 & 0.23 & 0.00 & 0.00 & 0.00 & 0.00 & 0.00 \\
\hline Metachromadora & $2 \mathrm{~B}$ & 3.84 & 10.84 & 0.34 & 0.59 & 13.05 & 9.11 & 4.39 & 17.53 \\
\hline Metaparoncholaimus & $2 \mathrm{~B}$ & 0.00 & 0.00 & 0.29 & 0.00 & 0.00 & 0.00 & 0.00 & 0.00 \\
\hline Metepsilonema & $1 \mathrm{~A}$ & 1.03 & 1.49 & 0.00 & 0.00 & 0.00 & 0.00 & 0.00 & 0.00 \\
\hline Metoncholaimus & $2 \mathrm{~B}$ & 0.00 & 0.00 & 0.00 & 0.00 & 0.00 & 0.00 & 0.00 & 6.50 \\
\hline Microlaimus & $2 \mathrm{~A}$ & 0.99 & 2.18 & 0.00 & 0.00 & 1.84 & 0.06 & 1.73 & 0.00 \\
\hline Molgolaimus & $1 \mathrm{~A}$ & 0.17 & 0.00 & 0.00 & 0.00 & 0.16 & 0.00 & 0.00 & 0.00 \\
\hline Neochromadora & $2 \mathrm{~A}$ & 0.14 & 0.00 & 0.00 & 0.00 & 0.00 & 0.00 & 0.00 & 0.00 \\
\hline Nygmatonchus & $2 \mathrm{~A}$ & 2.21 & 2.39 & 0.00 & 0.00 & 13.78 & 32.79 & 0.00 & 13.33 \\
\hline Odontophoroides & $2 \mathrm{~A}$ & 0.00 & 0.00 & 0.00 & 0.13 & 0.00 & 0.00 & 0.00 & 0.00 \\
\hline Onchium & $2 \mathrm{~A}$ & 0.00 & 0.00 & 0.41 & 0.43 & 0.00 & 0.00 & 0.81 & 0.20 \\
\hline Oncholaimidae type I & $2 \mathrm{~B}$ & 0.00 & 0.00 & 0.00 & 0.00 & 0.00 & 0.00 & 0.66 & 0.00 \\
\hline Oncholaimus & $2 \mathrm{~B}$ & 5.33 & 12.21 & 4.30 & 0.30 & 1.17 & 0.73 & 0.00 & 9.52 \\
\hline Oxystomina & $1 \mathrm{~A}$ & 0.00 & 0.00 & 1.36 & 3.98 & 0.00 & 0.00 & 0.00 & 0.00 \\
\hline Paracanthoncus & $2 \mathrm{~A}$ & 0.00 & 3.14 & 0.00 & 0.00 & 23.94 & 2.34 & 2.25 & 2.92 \\
\hline Paracyatholaimus & $2 \mathrm{~A}$ & 12.10 & 8.32 & 0.18 & 0.64 & 0.16 & 0.64 & 0.00 & 0.00 \\
\hline Perepsilonema & $1 \mathrm{~A}$ & 1.58 & 1.69 & 0.00 & 0.00 & 0.00 & 0.00 & 0.00 & 0.00 \\
\hline
\end{tabular}


APPENDIX A (CONTINUATION)

\begin{tabular}{|c|c|c|c|c|c|c|c|c|c|}
\hline \multirow{3}{*}{ Genera } & \multirow{3}{*}{ FT } & \multicolumn{4}{|c|}{ Coqueiros } & \multicolumn{4}{|c|}{ Bananal } \\
\hline & & \multicolumn{2}{|c|}{ Upper } & \multicolumn{2}{|c|}{ Lower } & \multicolumn{2}{|c|}{ Upper } & \multicolumn{2}{|c|}{ Lower } \\
\hline & & Jan & Jun & Jan & Jun & Jan & Jun & Jan & Jun \\
\hline Phanoderma & $2 \mathrm{~A}$ & 1.19 & 0.55 & 0.00 & 0.00 & 0.00 & 0.00 & 0.00 & 0.00 \\
\hline Phanodermatidae type I & $1 \mathrm{~A}$ & 0.33 & 0.00 & 0.00 & 0.00 & 0.00 & 0.00 & 0.00 & 0.00 \\
\hline Rhabditis & $1 \mathrm{~A}$ & 0.00 & 0.00 & 0.00 & 0.00 & 0.16 & 0.00 & 0.00 & 0.00 \\
\hline Rhips & $2 \mathrm{~A}$ & 0.00 & 0.00 & 0.18 & 0.00 & 0.00 & 0.00 & 0.00 & 0.00 \\
\hline Sabatieria & $1 \mathrm{~B}$ & 0.00 & 0.00 & 49.60 & 62.80 & 0.00 & 0.00 & 1.73 & 1.42 \\
\hline Subsphaerolaimus & $1 \mathrm{~B}$ & 0.33 & 1.77 & 0.00 & 0.16 & 2.95 & 1.80 & 0.00 & 0.00 \\
\hline Terschellingia & $1 \mathrm{~A}$ & 0.00 & 0.00 & 0.00 & 0.19 & 0.00 & 0.00 & 0.00 & 0.00 \\
\hline Theristus & $1 \mathrm{~B}$ & 0.99 & 4.99 & 0.84 & 0.47 & 0.46 & 0.35 & 75.00 & 10.18 \\
\hline Trefusia & $1 \mathrm{~A}$ & 0.51 & 1.01 & 0.00 & 0.00 & 0.18 & 0.00 & 0.00 & 0.00 \\
\hline Trileptium & $2 \mathrm{~B}$ & 0.14 & 0.00 & 0.40 & 0.00 & 2.56 & 6.06 & 0.00 & 0.00 \\
\hline Trissonchulus & $2 \mathrm{~B}$ & 9.01 & 2.44 & 0.91 & 0.00 & 20.82 & 9.36 & 0.94 & 0.20 \\
\hline Viscosia & $2 \mathrm{~B}$ & 3.69 & 0.00 & 0.00 & 0.13 & 0.00 & 0.00 & 0.00 & 1.22 \\
\hline
\end{tabular}

